\title{
PENGARUH PENERAPAN GOOD CORPORATE GOVERNANCE TERHADAP STRUKTUR MODAL PERUSAHAAN GO PUBLIC YANG TERCATAT DI BURSA EFEK INDONESIA
}

\author{
ERIKA SEPTIANTY \\ Pascasarjana FEB Universitas Brawijaya Malang \\ Jl. Mayjen Haryono 165 Malang, No Telp: 085246732668
}

\begin{abstract}
Good Corporate Governance (GCG) is increasingly popular. but has a very important meaning in the system of corporate governance and managerial aspects, and investing in a good organization profit organization and this research uses its capital structure as measured by the debt-equity ratio as the dependent variable, while institutional ownership and managerial ownership as well as company size and profitability as the independent variable and three control variables. Control variables are variables that are controlled or held constant so that the effect $o$ outside factors. Control variables used in the study include the Board of Directors, non-executive directors, and chair duality. Research is underway to find empirical evidence of the influence of the implementation of Good Corporate governanve the company's capital structure. The population used in this study is a company listed on the Indonesia Stock Exchange, while the sample is a company in the implementation of corporate governance ranking by IICG during the period 2005-2011. From the results of testing the hypothesis, suggesting that the effect of corporate governance is proxied by managerial ownership, institutional ownership and firm size has no influence not have any impact on capital structure. The research proves that the variables have an influence on the profitability of capital structure. In general, the results of this study indicate that companies listed on the Stock Exchange has not fully considering the use of corporate governance in determining capital structure.

Keyword: Managerial Ownership, Institutional Ownership, Profitability, Firm Size, Good Corporate Governance, Capital Structure.
\end{abstract}

\begin{abstract}
ABSTRAK
Good Corporate Governance (GCG) semakin populer. namun mempunyai arti yang sangat penting dalam sistem tata kelola perusahaan maupun dalam aspek manajerial dan investasi dalam suatu organisasi baik organisasi laba dan nonlaba.Penelitian ini menggunakan struktur modal yang diukur dengan debtequity ratio sebagai variabel dependen, sedangkan kepemilikan institusional dan kepemilikan manajerial, serta ukuran perusahaan dan profitabilitas sebagai variabel independen dan tiga variabel kontrol. Variabel kontrol merupakan
\end{abstract}


variabel yang dikendalikan atau dibuat konstan sehingga pengaruh variabel independen terhadap variabel dependen tidak dipengaruhi oleh faktor luar yang tidak diteliti. Variabel kontrol yang digunakan dalam penelitian antara lain Dewan Direksi, non-executive directors, dan chair duality. Penelitian ini dilakukan untuk menemukan bukti empris adanya pengaruh penerapan Good Corporate governanve terhadap struktur modal perusahaan. Populasi yang digunakan dalam penelitian ini adalah perusahaan yang terdaftar di Bursa Efek Indonesia, sedangkan sampel adalah perusahaan yang masuk dalam pemeringkatan penerapan corporate governance yang dilakukan oleh IICG selama periode 2005-2011. Dari hasil pengujian hipotesis, menunjukkan bahwa pengaruh corporate governance yang diproksikan oleh kepemilikan manajerial, kepemilikan institusional dan ukuran perusahaan tidak mempunyai pengaruh terhadap struktur modal. Hasil penelitian membuktikan bahwa variabel profitabilitas mempunyai pengaruh terhadap struktur modal.Secara umum hasil penelitian ini menunjukkan bahwa perusahaan yang terdaftar di BEI belum sepenuhnya memperhatikan penggunaan corporate governance dalam menentukan kebijakan struktur modalnya,

kata kunci: good corporate governanve, kepemilikan manajerial, kepemilikan institusional, profitabilitas, ukuran perusahaan, struktur modal

\section{PENDAHULUAN}

\section{Latar Belakang}

Pengaruh penerapan good corporate governance terhadap struktur modal suatu perusahaan merupakan topik yang menurut penulis sangat penting karena menjaga kemampuan perusahaan mengatur tata kelola keuangan maupun sumber pembiayaannya dengan baik. Dimana salah satu indikator tata kelola yang baik itu dilihat dari struktur kepemilikan perusahaan tersebut. Pendekatan corporate governance merupakan mekanisme untuk melindungi kepentingan pihak minoritas dari adanya teori keagenan yang dilakukan oleh pihak-pihak pengendali atau manajer. Corporate governance yang merupakan konsep yang didasarkan pada teori keagenan yang bisa berfungsi sebagai alat untuk memberi keyakinan kepada investor bahwa mereka akan menerima return atas dana yang mereka investasikan. Masalah struktur modal berkaitan dengan keputusan pendanaan yang dilakukan perusahaan. Manajer akan lebih percaya pada pandangan tradisional yang menyatakan bahwa struktur modal memengaruhi nilai perusahaan. Kebijakan struktur modal juga dipengaruhi oleh manajemen sebagai pembuat kebijakan perusahaan. Manajemen dibentuk untuk menjalankan aktivitas usaha, dan mencapai tujuan, visi dan misi perusahaan. Namun adakalanya 
kebijakan yang dibuat tidak selaras dengan tujuan perusahaan, karena manajemen memiliki kepentingan tersendiri. Oleh karenanya untuk menghindari permasalahan antara agensi dan prinsipal, maka perlunya dilakukan pengendalian aktivitas manajemen. Salah satu bentuk pengendalian manajemen adalah dengan membentuk kepemilikan manajerial. Adanya kepemilikan manajerial, akan menjadikan manajemen sebagai pemilik perusahaan, sehingga pihak manajemen akan berupaya semaksimal mungkin untuk meningkatkan aktivitas perusahaan untuk mendapat keuntungan, sekaligus akan membuat kebijakan yang baik, untuk menghindari risiko usaha yang mungkin terjadi.

Aktivitas manajerial juga dapat dikendalikan oleh pembentukan kepemilikan institusional. Pihak institusi sebagai bagian dari pemilik perusahaan, akan berupaya mengawasi setiap kinerja dan kebijakan yang dibuat oleh manajemen dalam menjalankan tugasnya, untuk meminimalkan risiko usaha yang mungkin terjadi, dan tujuan perusahaan untuk menghasilkan keuntungan dapat tercapai.

\section{Motivasi Penelitian}

Struktur modal merupakan salah satu kebijakan manajemen yang sangat penting bagi keberlangsungan perusahaan, karena struktur modal berkaitan dengan finansial perusahaan. Penggunaan hutang yang besar akan dapat dimanfaatkan oleh perusahaan untuk meningkatkan kemampuannya dalam memperbesar modal, mengembangkan kegiatan usaha dan meningkatkan pendapatan dan keuntungan. Namun hutang yang besar juga akan dapat menimbulkan risiko finansial, yang berdampak pada kebangkrutan perusahaan, jika tidak dikelola dengan baik. Oleh karena itu manajemen perusahaan harus berhati-hati dalam menetapkan struktur modal, dan memperhatikan struktur modal yang optimal. Bagi investor, kondisi struktur modal perusahaan juga harus diperhatikan, untuk menghindari risiko kerugian dalam berinvestasi saham. Oleh karena itu investor juga harus memahami dan memperhatikan faktor-faktor yang memengaruhi struktur modal perusahaan.

Permasalahan yang diangkat adalah sebagai berikut: (1) Apakah Kepemilikan Manajerial berpengaruh terhadap struktur modal perusahaan?, (2) Apakah 
Kepemilikan Institusional berpengaruh terhadap struktur modal perusahaan?, (3) Apakah ukuran perusahaan berpengaruh terhadap struktur modal perusahaan?, (4) Apakah profitabilitas berpengaruh terhadap struktur modal perusahaan?

\section{TINJAUAN PUSTAKA}

\section{Landasan Teori}

Hubungan keagenan dapat menimbulkan masalah pada saat pihak-pihak yang bersangkutan mempunyai tujuan yang berbeda. Pemilik modal menghendaki bertambahnya kekayaan dan kemakmuran para pemilik modal, sedangkan manajer juga menginginkan bertambahnya kesejahteraan bagi para manajer. Dengan demikian, muncullah konflik kepentingan antara pemilik (investor) dengan manajer (agen). Pemilik lebih tertarik untuk memaksimumkan return dan harga sekuritas dari investasinya, sedangkan manajer mempunyai kebutuhan psikologis dan ekonomi yang luas, termasuk memaksimumkan kompensasinya. Kontrak yang dibuat antara pemilik dengan manajer diharapkan dapat meminimumkan konflik antar kedua kepentingan tersebut. Teori keagenan dilandasi dengan tiga asumsi (Eisenhardt, 1989), yaitu: asumsi sifat manusia (human assumptions), asumsi keorganisasian (organizational assumptions), dan asumsi informasi (information assumptions). Asumsi sifat manusia dikelompokkan menjadi tiga, yaitu: (1) self-interest, yaitu sifat manusia untuk mengutamakan kepentingan diri sendiri, (2) bounded-rationality, yaitu sifat manusia yang memiliki keterbatasan rasionalitas, dan (3) risk aversion, yaitu sifat manusia yang lebih memilih mengelak dari risiko. Asumsi keorganisasian dikelompokkan menjadi tiga, yaitu: (1) konfik sebagian tujuan antar partisipan, (2) efisiensi sebagai suatu kriteria efektivitas, dan (3) asimetri informasi antara pemilik dan agen. Asumsi informasi merupakan asumsi yang menyatakan bahwa informasi merupakan suatu komoditas yang dapat dibeli.

Corporate governance merupakan suatu mekanisme pengelolaan yang didasarkan pada teori keagenan. Penerapan konsep corporate governance diharapkan memberikan kepercayaan terhadap agen (manajemen) dalam mengelola kekayaan pemilik (investor), dan pemilik menjadi lebih yakin bahwa agen tidak akan 
melakukan suatu kecurangan untuk kesejahteraan agen. Forum for Corporate Governance in Indonesia/ FCGI (2001) mendefinisikan corporate governance sebagai seperangkat peraturan yang mengatur hubungan antara pemegang saham, pengurus (pengelola) perusahaan, pihak kreditur, pemerintah, karyawan, serta para pemegang kepentingan internal dan eksternal lainnya yang berkaitan dengan hak-hak dan kewajiban mereka sehingga menciptakan nilai tambah bagi semua pihak yang berkepentingan (stakeholder). Penerapan corporate governance memberikan empat manfaat (FCGI, 2001), yaitu: (1) meningkatkan kinerja perusahaan melalui terciptanya proses pengambilan keputusan yang lebih baik, meningkatkan efisiensi perusahaan, serta lebih meningkatkan pelayanan kepada stakeholders, (2) mempermudah diperolehnya dana pembiayaan yang lebih murah dan tidak rigit (karena faktor kepercayaan) yang pada akhirnya akan meningkatkan corporate value, (3) mengembalikan kepercayaan investor untuk menanamkan modalnya di Indonesia, dan (4) pemegang saham akan merasa puas dengan kinerja perusahaan karena sekaligus akan meningkatkan shareholders's values dan dividen. Salah satu prinsip corporate governance menurut Organization for Economic Cooperation and Development (OECD) adalah menyangkut peranan dewan komisaris. Bentuk dewan komisaris tergantung pada sistem hukum yang dianut. Terdapat dua sistem yang berbeda, yaitu Anglo Saxon dan Kontinental Eropa (FCGI, 2001a). Dalam sistem hukum Anglo Saxon, sistem yang dianut adalah sistem satu tingkat atau one tier system. Terdapat tiga elemen penting yang akan memengaruhi tingkat efektivitas dewan komisaris, yaitu independensi, kompetensi, dan komitmen. Independensi diharapkan timbul dengan keberadaan komisaris independen. Kompetensi tercipta dengan adanya komite-komite yang dibentuk dewan komisaris, terutama komite audit. Keberadaan komisaris independen dimaksudkan untuk menciptakan iklim yang lebih objektif dan independen, dan juga untuk menjaga "fairness" serta mampu memberikan keseimbangan antara kepentingan pemegang saham mayoritas dan perlindungan terhadap kepentingan pemegang saham minoritas, bahkan kepentingan para stakeholder lainnya (Setyapurnama dan Norpratiwi, 2003). Manajer sekaligus pemilik mempunyai anggapan bahwa utang yang tinggi akan 
menyebabkan risiko kebangkrutan sehingga membuat manajer sensitif terhadap kinerja perusahaan dan atas dasar pemikiran tersebut maka manajer akan meningkatkan kepemilikan sahamnya sehingga manajer akan dapat ikut serta dalam keputusan perusahaan (Fatmawati, 2008).

Peningkatan kepemilikan institusional akan menggantikan peranan manajerial sehingga dapat meminimumkan agency cost dalam perusahaan. Melalui mekanisme kepemilikan institusional, efektivitas pengelolaan sumber daya perusahaan oleh manajemen dapat diketahui dari informasi yang dihasilkan melalui reaksi pasar atas pengumuman laba. Kepemilikan institusional memiliki kemampuan untuk mengendalikan pihak manajemen melalui proses monitoring secara efektif sehingga mengurangi tindakan manajemen melakukan manajemen laba. Persentase saham tertentu yang dimiliki oleh institusi dapat mempengaruhi proses penyusunan laporan keuangan yang tidak menutup kemungkinan terdapat akrualisasi sesuai kepentingan pihak manajemen. Semakin besar kepemilikan saham yang dimiliki institusi akan lebih memudahkan dalam pengawasan dan upaya untuk mengendalikan sikap oportunis manajemen karena akan mengurangi agency cost pada perusahaan serta penggunaan utang oleh manajemen.

Melalui mekanisme kepemilikan institusional, efektivitas pengelolaan sumber daya perusahaan oleh manajemen dapat diketahui dari informasi yang dihasilkan melalui reaksi pasar atas pengumuman laba. Kepemilikan institusional memiliki kemampuan untuk mengendalikan pihak manajemen melalui proses monitoring secara efektif sehingga mengurangi tindakan manajemen melakukan manajemen laba. Persentase saham tertentu yang dimiliki oleh institusi dapat mempengaruhi proses penyusunan laporan keuangan yang tidak menutup kemungkinan terdapat akrualisasi sesuai kepentingan pihak manajemen. Semakin besar kepemilikan saham yang dimiliki institusi akan lebih memudahkan dalam pengawasan dan upaya untuk mengendalikan sikap oportunis manajemen karena akan mengurangi agency cost pada perusahaan serta penggunaan utang oleh manajemen.

Profitabilitas memiliki hubungan dengan utang. Adanya hubungan negatif antara profitabilitas dengan utang karena kreditor cenderung memberikan 
pinjaman kepada perusahaan dengan laba/aliran kas tinggi. Profitabilitas diukur dengan Return On Asset (Hanafi, 2008:321). Struktur modal merupakan keputusan penting suatu perusahaan yang terkait dengan keuangan perusahaan. Martono dan Harjito (2004:240) menyatakan bahwa struktur modal (capital structure) adalah perbandingan atau imbangan pendanaan jangka panjang terhadap modal sendiri. Pemenuhan kebutuhan dana perusahaan dari sumber modal sendiri berasal dari modal saham, laba ditahan, dan cadangan. Jika dalam pendanaan perusahaan dari modal sendiri masih mengalami kekurangan, perlu dipertimbangkan pendanaan perusahaan yang berasal dari luar, yaitu dari utang (debt financing). Sumber pembiayaan ini dapat diperoleh dari dalam dan dari luar perusahaan. Keputusan pembiayaan akan mempengaruhi struktur modal Biaya modal perusahaan akan semakin menurun dengan makin besarnya komposisi utang yang dipergunakan. Penggunaan utang akan menurunkan biaya modal dan meningkatkan nilai perusahaan. Tetapi, semakin tinggi tingkat utang akan meningkatkan risiko yang harus ditanggung perusahaan. Dengan proporsi utang yang yang makin besar akan berpengaruh pula pada kemungkinan perolehan rating perusahaan. Prinsip pokok atas penggunaan utang adalah keseimbangan antara keuntungan dan kerugian penggunaan utang, yaitu diperolehnya nilai perusahaan yang maksimal dengan biaya modal yang minimum.

\section{Penelitian Terdahulu}

\section{Tabel 1}

Rangkuman Penelitian Terdahulu

\begin{tabular}{|l|l|l|l|l|}
\hline No & \multicolumn{1}{|c|}{ Peneliti } & \multicolumn{1}{|c|}{ Variabel } & \multicolumn{1}{c|}{ Analisis } & \multicolumn{1}{c|}{ Hasil } \\
\hline $\begin{array}{l}\text { Evans } \text { et al. } \\
(2002)\end{array}$ & $\begin{array}{l}\text { Variabel independen: } \\
\text { corporate governance } \\
\text { Variabel dependen: } \\
\text { Penurunan kinerja }\end{array}$ & $\begin{array}{l}\text { Regresi } \\
\text { berganda }\end{array}$ & $\begin{array}{l}\text { Tidak ada pengaruh } \\
\text { antara rasio komisaris } \\
\text { independen dengan } \\
\text { kinerja perusahaan }\end{array}$ \\
\hline $\begin{array}{l}\text { Wahidahwa } \\
\text { ti (2002) }\end{array}$ & $\begin{array}{l}\text { Variabel independen: } \\
\text { corporate governance } \\
\text { Variabel dependen: } \\
\text { kebijakan pendanaan }\end{array}$ & $\begin{array}{l}\text { Regresi } \\
\text { berganda }\end{array}$ & $\begin{array}{l}\text { Kepemilikan manajer } \\
\text { dan institusi } \\
\text { berhubungan negatif } \\
\text { dengan rasio utang } \\
\text { perusahaan }\end{array}$ \\
\hline
\end{tabular}




\begin{tabular}{|c|c|c|c|}
\hline $\begin{array}{l}\text { Kang } \\
(2004)\end{array}$ & $\begin{array}{l}\text { Variabel independen: } \\
\text { corporate governance } \\
\text { Variabel dependen: } \\
\text { Kinerja operasi }\end{array}$ & $\begin{array}{l}\text { Regresi } \\
\text { berganda }\end{array}$ & $\begin{array}{l}\text { Komisaris independen } \\
\text { berpengaruh terhadap } \\
\text { kinerja perusahaan }\end{array}$ \\
\hline $\begin{array}{l}\text { Nishat } \\
(2004)\end{array}$ & $\begin{array}{l}\text { Variabel independen: } \\
\text { Kepemilikan individu, } \\
\text { kepemilikan keluarga, } \\
\text { kepemilikan } \\
\text { perusahaan, } \\
\text { CEO } \\
\text { Variabel dependen: } \\
\text { Kinerja perusahaan }\end{array}$ & $\begin{array}{l}\text { Regresi } \\
\text { berganda }\end{array}$ & $\begin{array}{l}\text { 1. struktur tata kelola } \\
\text { perusahaan oleh } \\
\text { individu dan } \\
\text { anggota keluarga } \\
\text { dan oleh } \\
\text { perusahaan- } \\
\text { perusahaan industri } \\
\text { berdampak positif } \\
\text { pada kinerja } \\
\text { perusahaan } \\
\text { 2. CEO berpengaruh } \\
\text { negative terhadap } \\
\text { kinerja perusahaan. }\end{array}$ \\
\hline $\begin{array}{l}\text { Kumar } \\
(2005)\end{array}$ & $\begin{array}{l}\text { Variabel independen: } \\
\text { Kepemilikan } \\
\text { perusahaan } \\
\text { Variabel dependen: } \\
\text { Struktur modal }\end{array}$ & $\begin{array}{l}\text { Regresi } \\
\text { berganda }\end{array}$ & $\begin{array}{l}\text { 1. Perusahaan yang } \\
\text { kurang dalam } \\
\text { mekanisme } \\
\text { corporate } \\
\text { governance yang } \\
\text { didispersikan dalam } \\
\text { pola kepemilikan } \\
\text { cenderung memiliki } \\
\text { tingkat utang yang } \\
\text { tinggi }\end{array}$ \\
\hline $\begin{array}{l}\text { Masdupi } \\
(2005)\end{array}$ & $\begin{array}{l}\text { Variabel independen: } \\
\text { Kepemilikan institusi, } \\
\text { kepemilikan insider } \\
\text { ownership, } \\
\text { Variabel dependen: } \\
\text { Kebijakan utang } \\
\text { Variabel control } \\
\text { Kebijakan dividen } \\
\text { ukuran perusahaan, } \\
\text { asset perusahaan, } \\
\text { profitabilitas, tax rate }\end{array}$ & $\begin{array}{l}\text { Regresi } \\
\text { berganda }\end{array}$ & $\begin{array}{l}\text { 1. Insider ownership } \\
\text { dan berpengaruh } \\
\text { negatif terhadap } \\
\text { kebijakan utang } \\
\text { 2. Kebijakan dividen, } \\
\text { ukuran perusahaan, } \\
\text { asset perusahaan, } \\
\text { profitabilitas dan } \\
\text { tax rate tidak } \\
\text { berpengaruh } \\
\text { terhadap kebijakan } \\
\text { utang. }\end{array}$ \\
\hline $\begin{array}{l}\text { Yuhasril, } \\
2006\end{array}$ & $\begin{array}{l}\text { Variabel independen: } \\
\text { ROI, fixed asset ratio, } \\
\text { dividen payout ratio } \\
\text { Variabel dependen: } \\
\text { Struktur modal }\end{array}$ & $\begin{array}{l}\text { Regresi } \\
\text { berganda }\end{array}$ & $\begin{array}{l}\text { 1. ROI, dan fixed } \\
\text { asset ratio } \\
\text { berpengaruh } \\
\text { terhadap struktur } \\
\text { modal } \\
\text { 2. dividen payout ratio } \\
\text { tidak berpengaruh }\end{array}$ \\
\hline
\end{tabular}




\begin{tabular}{|c|c|c|c|}
\hline & & & $\begin{array}{l}\text { terhadap struktur } \\
\text { modal }\end{array}$ \\
\hline $\begin{array}{l}\text { Diana dan } \\
\text { Irianto } \\
(2008)\end{array}$ & $\begin{array}{l}\text { Variabel independen: } \\
\text { Kepemilikan } \\
\text { manajerial, kepemilikan } \\
\text { institusional, } \\
\text { sebaran kepemilikan, } \\
\text { Variabel control: } \\
\text { pembayaran dividen, } \\
\text { ukuran perusahaan, } \\
\text { struktur aktiva, } \\
\text { profitabilitas, } \\
\text { pembayaran pajak } \\
\text { Variabel dependen: } \\
\text { Kebijakan utang }\end{array}$ & $\begin{array}{l}\text { Regresi } \\
\text { berganda }\end{array}$ & $\begin{array}{l}\text { 1. Kepemilikan } \\
\text { manajerial, } \\
\text { kepemilikan } \\
\text { institusional, } \\
\text { penyebaran } \\
\text { kepemilikan, } \\
\text { mempunyai } \\
\text { pengaruh negatif } \\
\text { terhadap kebijakan } \\
\text { utang. }\end{array}$ \\
\hline $\begin{array}{l}\text { Arshad } \\
\text { Hasan dan } \\
\text { Safdar Ali } \\
\text { Butt (2009) }\end{array}$ & $\begin{array}{l}\text { Variabel independen: } \\
\text { Institutional Share } \\
\text { Holding, Managerial } \\
\text { Shareholding. } \\
\text { Variabel control: } \\
\text { dewan komisaris, Non } \\
\text { Executive Directors, } \\
\text { ukuran perusahaan, } \\
\text { Return on Assets, } \\
\text { Variabel dependen: } \\
\text { struktur modal }\end{array}$ & $\begin{array}{l}\text { regresi } \\
\text { multivariat }\end{array}$ & $\begin{array}{l}\text { 1. Ukuran perusahaan } \\
\text { dan kepemilikan } \\
\text { manajerial } \\
\text { berkorelasi negatif } \\
\text { dengan struktur } \\
\text { modal. } \\
\text { 2. CEO, NED, tidak } \\
\text { berpengaruh } \\
\text { terhadap struktur } \\
\text { modal } \\
\text { 3. Ukuran perusahaan } \\
\text { dan ROA } \\
\text { berpengaruh } \\
\text { terhadap struktur } \\
\text { modal. } \\
\text { 4. Good corporate } \\
\text { governance seperti } \\
\text { ukuran dan } \\
\text { kepemilikan } \\
\text { institusional dan } \\
\text { kepemilikan } \\
\text { manajerial } \\
\text { memainkan peran } \\
\text { penting dalam } \\
\text { penentuan struktur } \\
\text { modal perusahaan. }\end{array}$ \\
\hline $\begin{array}{l}\text { Ernawati } \\
\text { (2011) }\end{array}$ & $\begin{array}{l}\text { Variabel independen: } \\
\text { ukuran perusahaan, } \\
\text { struktur aktiva, } \\
\text { profitabilitas }\end{array}$ & $\begin{array}{l}\text { Regresi } \\
\text { berganda }\end{array}$ & $\begin{array}{l}\text { 1. ukuran perusahaan, } \\
\text { struktur aktiva, } \\
\text { profitabilitas } \\
\text { berpengaruh }\end{array}$ \\
\hline
\end{tabular}




\begin{tabular}{|l|l|l|l|}
\hline & $\begin{array}{l}\text { Variabel dependen: } \\
\text { Struktur modal }\end{array}$ & & $\begin{array}{l}\text { terhadap struktur } \\
\text { modal. }\end{array}$ \\
\hline
\end{tabular}

\section{KERANGKA PENELITIAN}

\section{Kerangka Konseptual}

Penelitian ini menguji seberapa besar pengaruh corporate governance terhadap struktur modal. Berdasarkan penelitian Hasan dan Butt (2009) peneliti menggunakan struktur modal perusahaan yang terdiri atas debt to equity ratio sebagai variabel dependen, sedangkan untuk variabel independennya peneliti menggunakan variabel Good Corporate Governace yang terdiri atas kepemilikan manajerial, kepemilikan institusional, profitabilitas dan ukuran perusahaan. Dalam penelitian ini, peneliti menggunakan tiga variabel kontrol yaitu board-size, non-executive directors, dan chair duality. Alur pemikiran kerangka konseptual adalah sebagai berikit:

Gambar 1

Kerangka Konseptual

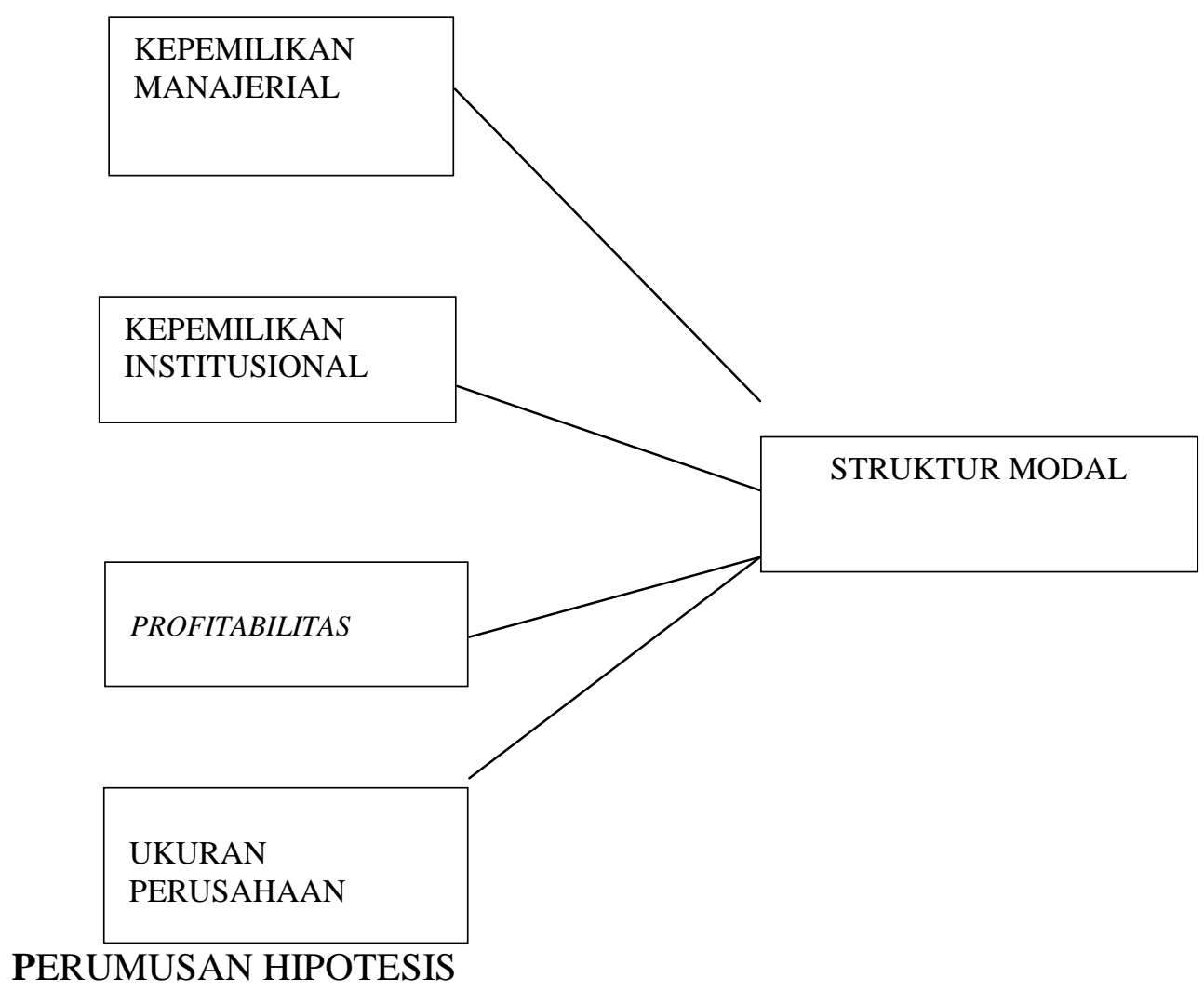


$\mathrm{H}^{1}$ : Kepemilikan manajerial berpengaruh positif terhadap struktur modal perusahaan.

$\mathrm{H}^{2}$ : Kepemilikan institusional berpengaruh positif terhadap struktur modal perusahaan.

$\mathrm{H}_{3}$ : Ukuran perusahaan berpengaruh positif terhadap struktur modal perusahaan.

$\mathrm{H}_{4}$ : Profitabilitas berpengaruh positif terhadap struktur modal perusahaan.

\section{METODE PENELITIAN}

\section{PENDEKATAN DAN OBJEK PENELITIAN}

Penelitian ini menggunakan pendekatan kuantitatif. Penelitian kuantitatif bertujuan untuk menguji secara statistik ada tidaknya pengaruh variabel independen terhadap variabel dependen. Ditinjau dari jenis penelitian, maka penelitian ini tergolong penelitian explanatori atau penjelasan.

Penelitian ini dilakukan di Bursa Efek Indonesia (BEI) dengan objek penelitiannya adalah perusahaan yang go public di BEI. Periode pengamatannya yang digunakan adalah tahun 2005-2011. Alasan pengambilan masa pengamatan tersebut karena dalam penelitian ini perusahaan go public yang diamati adalah perusahaan go public di BEI yang terpilih dalam peringkat penerapan good corporate governance yang dilakukan oleh The Indonesian Institute for Corporate Governance (IICG) sehingga dengan periode pengamatan tersebut diharapkan mampu merepresentatifkan perusahaan go public yang melakukan good corporate governance dengan baik.

\section{Populasi Dan Metode Pengambilan Sampel}

Beberapa kriteria yang ditetapkan untuk memperoleh sampel meliputi:

1. Perusahaan sampel adalah perusahaan yang tercatat di Bursa Efek Indonesia tahun 2005-2011;

2. Perusahaan yang tetap beroperasi sampai dengan bulan Desember 2010, tidak melakukan delisting, tidak melakukan penggabungan usaha selama tahun 2005-2011; 
3. Perusahaan serta rutin memublikasikan laporan keuangannya selama periode 2005-2011 dan mempunyai laporan keuangan yang berakhir 31 Desember;

4. Perusahaan masuk pemeringkatan penerapan corporate governance yang dilakukan oleh The Indonesian Institute for Corporate Governance di tahun 2005 hingga tahun 2011.

5. Perusahaan bukan termasuk dalam kelompok perbankan dan lembaga keuangan.

Berdasarkan kriteria tersebut, maka penyaringan sampel dapat dilakukan sebagai berikut:

Tabel 2

Penyaringan Sampel Penelitian

\begin{tabular}{|c|c|c|c|c|c|c|c|}
\hline \multirow[t]{2}{*}{ Keterangan } & \multicolumn{7}{|c|}{ Perhitungan perusahaan sampel } \\
\hline & 2005 & 2006 & 2007 & 2008 & 2009 & 2010 & 2011 \\
\hline Perusahaan yang tercatat di BEI & 368 & 350 & 394 & 406 & 413 & 415 & 414 \\
\hline \multirow[t]{2}{*}{$\begin{array}{l}\text { Perusahaan yang telah } \\
\text { melakukan penggabungan usaha } \\
\text { baik merger atau akuisisi }\end{array}$} & $(0)$ & $(0)$ & $(0)$ & $(0)$ & $(0)$ & (1) & $(0)$ \\
\hline & 368 & 350 & 394 & 406 & 413 & 414 & 414 \\
\hline \multirow[t]{2}{*}{ Perusahaan yang delisted } & (3) & $(4)$ & $(8)$ & $(6)$ & (12) & (1) & $(0)$ \\
\hline & 365 & 346 & 386 & 400 & 401 & 413 & 414 \\
\hline \multirow[t]{2}{*}{$\begin{array}{l}\text { Perusahaan tidak masuk dalam } \\
\text { pemeringkatan penerapan } \\
\text { corporate governance yang } \\
\text { dilakukan oleh } I I C G \text { hingga } \\
\text { tahun } 2010\end{array}$} & $(355)$ & (336) & (376) & $(391)$ & (393) & $(403)$ & $(395)$ \\
\hline & 10 & 10 & 10 & 9 & 8 & 10 & 19 \\
\hline \multirow[t]{2}{*}{ Perusahaan perbankan/keuangan } & (5) & (3) & (4) & (3) & (1) & (4) & (7) \\
\hline & 5 & 7 & 6 & 3 & 7 & 6 & 13 \\
\hline Jumlah sampel & \multicolumn{7}{|c|}{47} \\
\hline
\end{tabular}

\section{Metode Analisis Data}

\section{Statistik Deskriptif}

Statistik deskriptif yang digunakan untuk mengetahui nilai rerata (mean), distribusi frekuensi, nilai maksimum dan minimum maupun deviasi standar. 
Analisis Regresi berganda (Multiple Regression Analysis)

Formulasi multiple regression dalam penelitian ini adalah

$$
\begin{array}{ll}
\text { LEVit }= & \beta_{0}+\beta_{1} \text { INSDR }+\beta_{2} \text { INST }+\beta_{3} \text { SZ }+\beta_{4} \text { PROF }+\varepsilon i \\
\text { LEVit }= & \beta_{0}+\beta_{1} \text { INSDR }+\beta_{2} \text { INST }+\beta_{3} \text { SZ }+\beta_{4} \text { PROB }+\beta_{5} \text { BZ }+\beta_{6} \text { NED } \\
& +\beta_{7} \text { DUAL }+\varepsilon i
\end{array}
$$

Keterangan:

$\begin{array}{ll}\text { LEV } & =\text { Leverage } \\ \mathrm{INSDR}= & \text { kepemilikan manajerial } \\ \mathrm{INST} & =\text { kepemilikan institusional } \\ \mathrm{SZ} & =\text { ukuran perusahaan } \\ \mathrm{PROF} & =\text { Profitabilitas } \\ \mathrm{BZ} & =\text { dewan direksi } \\ \mathrm{NED} & =\text { Non-Executive Director } \\ \mathrm{DUAL} & =\text { Chair Duality } \\ \boldsymbol{\beta}_{0} & =\text { Konstanta } \\ \beta_{1^{-7}} & =\text { Koefisien Regresi } \\ \boldsymbol{\varepsilon} \boldsymbol{i} & =\text { Error }\end{array}$

\section{HASIL PENELITIAN DAN PEMBAHASAN}

\section{Analisis Deskriptif}

Hasil analisis deskriptif dapat di lihat pada Tabel 1. Hasil analisis menunjukkan bahwa nilai rata-rata kepemilikan manajerial sebesar $0,35 \%$ dengan nilai minimum $0 \%$ dan nilai maksimum 0,8400 . Untuk kepemilikan institusional menunjukkan bahwa nilai rata-rata kepemilikan institusional sebesar 62,2402\% dengan nilai minimum sebesar 10,18\% dan nilai maksimum sebesar 98,18\%. Artinya, sebagian besar perusahaan sampel yang diteliti memiliki kepemilikan institusional. Nilai kepemilikan institusional yang tinggi menunjukkan bahwa perusahaan dimiliki oleh beberapa institusi yang berfungsi sebagai kontrol aktivitas usaha yang dijalankan perusahaan.

Pada variabel ukuran perusahaan dilihat bahwa nilai rata-rata ukuran perusahaan sebesar 30,0570 satuan dengan nilai minimum 25,97 satuan dan nilai maksimum sebesar 32,27 satuan. Hal ini menunjukkan bahwa kekayaan sebagian besar perusahaan yang diamati tidak terlalu jauh berbeda. Dengan jumlah kekayaan yang relatif sama dari perusahaan yang diamati, menjadikan perusahaan relatif memiliki peluang usaha, risiko usaha yang sama, dan juga memiliki 
kemampuan untuk menyediakan dana operasional yang relatif sama. Dengan kekayaan yang relatif sama juga akan memungkinkan perusahaan mempunyai tingkat leverage yang sama.

Variabel profitabilitas yang diukur dengan variabel ROA pada analisis deskriptif menunjukkan rata-rata profitabilitas sebesar $12,32 \%$ dengan nilai minimum sebesar $-6,76 \%$ dan nilai maksimum sebesar $42,64 \%$. Artinya, sebagian besar perusahaan yang menjadi sampel penelitian mampu menghasilkan keuntungan dari total aktiva yang dimilikinya. Besarnya keuntungan yang diperoleh oleh sebagian besar perusahaan yang menjadi sampel juga di atas suku bunga deposito sebesar 6\% untuk tahun 2011 (www.bi.go.id, 2012) sehingga dapat dikatakan bahwa kemampuan perusahaan dalam menghasilkan keuntungan adalah baik.

Hasil analisis deskriptif untuk variabel struktur modal adalah rata-rata struktur modal perusahaan yang diamati adalah 1,3915 atau 139,15\%. Artinya, sebagian besar perusahaan yang diamati memiliki struktur modal yang tinggi. Penggunaan struktur modal yang tinggi akan dapat meningkatkan risiko finansial. Oleh karenan itu, diperlukan pengawasan dan kontrol yang baik atas kebijakan manajemen terkait dengan penggunaan struktur modal yang tinggi. Banyaknya perusahaan yang menggunakan hutan sebagai sumber modal perusahaan karena adanya kebijakan Bank Indonesia untuk menurunkan suku bunga kredit dari 13,75\% pada awal 2010 turun menjadi 12,83\% (Bapepam, 2010). Kondisi ini dimanfaatkan oleh banyak perusahaan untuk menambah permodalan dari utang untuk peningkatan kegiatan usaha.

Tabel 3

Statistik Deskriftif Variabel

\begin{tabular}{|l|r|r|r|r|r|}
\hline VARIABEL & $\mathrm{N}$ & Minimum & Maksimum & Mean & Std. Deviasi \\
\hline INSDR & 47 &, 0000 &, 8400 &, 035047 &, 1317813 \\
INST & 47 & 10,18 & 98,18 & 62,2402 & 18,60320 \\
SIZE & 47 & 26,97 & 32,27 & 30,0570 & 1,30959 \\
PROF & 47 & $-6,76$ & 42,64 & 12,3236 & 8,64567 \\
BZ & 47 & 4,00 & 22,00 & 11,7234 & 3,42435 \\
\hline
\end{tabular}




\begin{tabular}{|c|c|c|c|c|c|}
\hline NED & 47 &, 00 & ,30 & , 1760 & ,06746 \\
\hline DUAL & 47 & ,00 & 1,00 & ,2553 & ,44075 \\
\hline Struktur Modal & 47 & ,19 & 7,75 & 1,3915 & 1,71834 \\
\hline Valid N & 47 & & & & \\
\hline (listwise) & I & & & & \\
\hline
\end{tabular}

Tabel 4

Hasil Pengujian Hipotesis (Tanpa variabel kontrol)

\begin{tabular}{|l|l|l|l|}
\hline Variabel & Beta & T & Sig. \\
\hline (constan) & & -.399 & .692 \\
\hline INSDR & -.061 & -.0503 & .618 \\
\hline INST & -.065 & -.517 & 608 \\
\hline SIZE & .092 & .748 & .459 \\
\hline PROF & -.563 & -4762 & .000 \\
\hline
\end{tabular}

Keterangan:

$\mathrm{F}: 6,587$

Nilai adj $R^{2}: 0,327$

Sumber: Data Diolah

\section{Analisis Regresi Linier Berganda}

\section{Uji asumsi klasik}

Pada uji autokorelasi yang bertujuan mendeteksi variabel pengganggu pada pada periode $\mathrm{t}$ dengan kesalahan pada periode t-1 (sebelumnya). Berdasarkan Lampiran 5 hasil pengujian autokorelasi menunjukkan bahwa nilai dw untuk persamaan pertama adalah 2,089. Nilai du untuk n $47 \mathrm{k} 4$ adalah 1,523 sehingga nilai du $<\mathrm{d}<$ 4-du adalah $1,523<2,089<(4-1,523)=1,523<2,089<2,477$ sehingga dapat dikatakan tidak ada masalah autokorelasi dan asumsi diterima.

Uji multikolinieritas bertujuan untuk menguji apakah pada model regresi ditemukan adanya korelasi antar variabel independen (Ghozali, 2007:91). Berdasarkan tabel 2 menunjukkan bahwa nilai variance inflation factor (VIF) baik persamaan I dan II di bawah 10 sehingga tidak ada masalah multikolinieritas, dan asumsi diterima.

Uji Heterokedastisitas bertujuan menguji apakah dalam sebuah model regresi terjadi ketidaksamaan varians dari residual dari satu pengamatan ke pengamatan yang lain (Ghozali, 2007:105), hasil uji glejser menunjukkan nilai sig t di atas $0,05(5 \%)$ sehingga tidak ada masalah heterokedastisitas, dan asumsi diterima. 
Dengan menggunakan uji normalitas, hasil penelitian menunjukkan bahwa nilai asym sig kolmogorov smirnov untuk persamaan I sebesar 0,666 dan persamaan II sebesar 0,945 Nilai tersebut di atas 0,05 (5\%) sehingga data terdistribusi normal, dan asumsi diterima.

\section{Pengujian Hipotesis}

Berdasarkan hasil anova menunjukkan bahwa kepemilikan manajerial, kepemilikan institusional, profitabilitas, dan ukuran perusahaan, secara bersamasama memengaruhi struktur modal. Adapun besarnya pengaruh secara bersamasama ditunjukkan oleh nilai koefisien diterminasi sebesar 0,327 atau sebesar 32,7\%. Artinya kepemilikan manajerial, kepemilikan institusional, profitabilitas, dan ukuran perusahaan memengaruhi struktur modal sebesar $32,7 \%$, sedangkan sisanya sebesar $67,3 \%$ dipengaruhi oleh faktor lain yang tidak diamati dalam penelitian ini.

Untuk menguji hipotesis, digunakan alat analisis regresi berganda dengan alat uji t. Berikut adalah hasil persamaan regresi untuk uji t:

\section{Stuktur Modal $=\quad-0,444-0,179$ INSDR - 0,001 INST + 0,027 SIZE - 0,026 PROF.}

Pengujian ini untuk membuktikan bahwa variabel INSDR, INST, SIZE, dan PROF mempunyai pengaruh postif terhadap struktur modal. Hasil uji $t$ kepemilikan manajerial (INSDR) menunjukkan nilai $t_{\text {hitung }}$ sebesar -0,503 dengan tingkat signifikansi sebesar 0,618 >0,05 ( > $\alpha=5 \%)$. Berdasarkan hasil tersebut dapat dikatakan bahwa kepemilikan manajerial (INSDR) tidak berpengaruh terhadap struktur modal.

Hasil uji t kepemilikan institusional (INST) menunjukkan nilai $t_{\text {hitung }}$ sebesar 0,517 dengan tingkat signifikansi sebesar 0,608 >0,05 ( > $\alpha=5 \%)$. Berdasarkan hasil tersebut maka dapat dikatakan bahwa kepemilikan institusional (INST) tidak berpengaruh terhadap struktur modal. 
Uji t untuk ukuran perusahaan (SIZE) menunjukkan nilai $t_{\text {hitung }}$ sebesar 0,748 dengan tingkat signifikansi sebesar 0,459>0,05 ( $>\alpha=5 \%)$. Berdasarkan hasil tersebut maka dapat dikatakan bahwa ukuran perusahaan (SIZE) tidak berpengaruh terhadap struktur modal

uji $t$ untuk profitabilitas (PROF) menunjukkan nilai $t_{\text {hitung }}$ sebesar $\quad-4,762$ dengan tingkat signifikansi sebesar 0,000 $<0,05(<\alpha=5 \%)$. Berdasarkan hasil tersebut maka dapat dikatakan bahwa profitabilitas (PROF) berpengaruh terhadap struktur modal.

\section{SIMPULAN}

Berdasarkan hasil pembahasan dapat disimpulkan bahwa variabel good corporate governance yang diukur dengan kepemilikan manajerial dan kepemilikan institusional dan ukuran perusahaan tidak terbukti memengaruhi struktur modal. Hanya variabel profitabilitas yang terbukti memengaruhi struktur modal. Namun secara bersama- sama variabel good corporate governance yang diukur dengan variabel kepemilikan manajerial, kepemilikan institusional, ukuran perusahaan dan profitabilitas mempunyai pengaruh terhadap variabel struktur modal.

\section{DAFTAR PUSTAKA}

Arshad, Hasan dan Safdar Ali Butt. 2009. Impact of Ownership Structure and Corporate Governance on Capital Stucture of Pakistani Listed Companies. International Journal of Business and Management 4 (Februari): No.2

Darmawati, Deni, Khomsiyah dan Rika Gelar Rahayu. 2005. Hubungan Corporate Governance dan Kinerja Perusahaan. Jurnal Riset Akuntansi Indonesia 8 (Jan): 65-81.

Darmawati, Deni, Khomsiyah, dan R.G Rahayu, 2005. Hubungan Corporate Governance dan Kinerja Perusahaan. Jurnal Riset Akuntansi Indonesia, vol 8, No 1, hal. 65-81

Diana, Devi Nurvida Avri dan Gugus Irianto. 2008. Pengaruh Kepemilikan Manajerial, Kepemilikan Institusional Dan Sebaran Kepemilikan Terhadap Kebijakan Hutang Perusahaan Ditinjau Dari Teori Keagenan. Emisi, Volume 1, (April): No.1(1-16)

Eisenhardt, Kathleen M. 1989. Agency Theory: An Assessment and Review. The Academy of management Review (Jan): 57-74. 
Ernawati. 2011. Pengaruh Ukuran Perusahaan, Struktur Aktiva Dan Profitabilitas Terhadap Struktur Modal Pada Perusahaan Manufaktur di BEI. Fakultas Ekonomi, Jurusan Akuntansi, Universitas Gunadarma. www.library. Gunadarma.ac.id. diakses 14 Maret 2012.

FCGI. 2001. Corporate Governance: Tata Kelola Perusahaan. Jilid I. FCGI,Edisi ke-3.

Ghozali, Imam. 2007. Aplikasi Analisis Multivariate Dengan Program SPSS. Cetakan IV. Badan Penerbit Universitas Diponegoro, Semarang.

Hanafi, Mamduh. 2008. Manajemen Keuangan. Edisi Pertama. Cetakan Kedua. BPFE. Yogyakarta.

Komite Nasional Kebijakan Corporate Governance (NCCG). 2001. Pedoman Good Corporate Governance. Ref. 4.0. NCCG.

Mamduh, M Hanafi. 2004. Manajemen Keuangan. Edisi Pertama. Penerbit BPFE. Yogyakarta

Masdupi, Erni. 2005. Analisis Dampak Struktur Kepemilikan Pada Kebijakan Hutang Dalam Mengontrol Konflik Keagenan. Jurnal Ekonomi dan Bisnis Indonesia. Vol. 20 No.1: (57-69)

Mulianti, Fitri Mega. 2010. Analisis Faktor-Faktor Yang Mempengaruhi Kebijakan Hutang Dan Pengaruhnya Terhadap Nilai Perusahaan (Studi Pada Perusahaan Manufaktur yang Terdaftar di Bursa Efek Indonesia (BEI) Periode Tahun 2004-2007). Tesis dipublikasikan. Program Studi Magister Manajemen Program Pasca Sarjana. Universitas Diponegoro, Semarang. www.google.com/ faktor-faktor nilai perusahaan. Diakses 28 Oktober 2011.

Mulianti, Fitri Mega. 2010. Analisis Faktor-Faktor Yang Mempengaruhi Kebijakan Hutang Dan Pengaruhnya Terhadap Nilai Perusahaan (Studi Pada Perusahaan Manufaktur yang Terdaftar di Bursa Efek Indonesia (BEI) Periode Tahun 2004-2007). Tesis dipublikasikan. Program Studi Magister Manajemen Program Pasca Sarjana. Universitas Diponegoro, Semarang. www.google.com/ faktor-faktor nilai perusahaan. Diakses 28 Oktober 2011.

Nugroho, Asih Suko. 2006. Analisis Faktor-Faktor Yang Mempengaruhi Struktur Modal Perusahaan Properti Yang Go Public Di Bursa Efek Jakarta Untuk Periode Tahun 1994-2004. Program Studi Magister Manajemen Program Pasca Sarjana. Universitas Diponegoro. Semarang. 
www.google.com/jurnalfaktor-faktoryang mempengaruhi struktur modal.pdf. diakses 14 Maret 2012.

Safdar, Ali Butt. 2009. Impact of Ownership Structure and Corporate Governance on Capital Structure of Pakistani Listed Companies. International Journal of Bussiner and Management. Vol 4. N0.2. Februari. www.ccsnet.org/journal.html. page 50-57

Sudarmadji, Ardi Murdoko dan Sularto, Lana. 2007. Pengaruh Ukuran Perusahaan, Profitabilitas, Leverage, dan Tipe Kepemilikan Perusahaan Terhadap Luas Voluntary Disclosure Laporan Keuangan Tahunan. Jurnal Proceeding PESAT (Psikologi, Ekonomi, Sastra, Arsitek \& Sipil) Auditorium Kampus Gunadarma. Vol. 2 ISSN : 1858-2559. 21-22 Agustus, 2007.hal :53-60.

Wahidahwati, 2002. Pengaruh Kepemilikan Manajerial dan Kepemilikan Institusional pada Kebijakan Hutang Perusahaan: Sebuah Perspektif Theory Agency. Jurnal Riset Akuntansi Indonesia. Vol. 5 No. 1 (1-16)

Yuhasril, 2006. Analisis Faktor-Faktor Yang Mempengaruhi Struktur Modal Perusahaan Farmasi Yang Telah Go Publik Di Bursa Efek Jakarta. Buletin Penelitian No.09. 